\title{
ULTRAVIOLET RADIATION TREATMENT OF THE DRUG «KENO CID 210»
}

\author{
T. Knyzhka, Candidate of Technical Sciences, Senior Lecturer \\ O. Romanenko, Candidate of Technical Sciences, Senior Lecturer \\ T. Tkachuk, engineer \\ B. Blyshchyk, student
}

National University of Life and Environmental Sciences of Ukraine

E-mail: knizhkatetiana@mail.ru

\begin{abstract}
The effectiveness of the process of photoactivation of aqueous solutions has been proven by studies conducted in the article.

As a method of exposure, UV radiation is low-cost and natural, so there is a need to study the effect of ultraviolet radiation on aqueous disinfectant solutions and to determine effective methods of irradiation.

Accordingly, there is a need to investigate the effect of $U V$ radiation on disinfectants, in particular on their antimicrobial properties and to determine the effective effect of ultraviolet radiation on the tool.

The high pressure mercury arc lamp DRT-400 lamp was used as a source of ultraviolet radiation. The surface of the aqueous solution was at a distance of $0.25 \mathrm{~m}$ under a source of UV radiation. The photoactivated liquid was applied to the agar medium immediately after inoculation of bacteria. The growth of colonies of microorganisms was recorded 24 hours after application of the treated disinfectant solution.

At the Department of Electrical Engineering, Electromechanics and Electrical Technologies of NULES of Ukraine measurements of $\mathrm{pH}$, redox potential of disinfectant solutions immediately after irradiation were carried out. Graphical dependences of changes of disinfecting properties are received.

It is established that ultraviolet radiation significantly changes the $p H$ and redox potential of aqueous solutions of disinfectants. The intensity of the parameter change is characteristic of ultraviolet radiation at an exposure of 5-15 minutes.

Irradiation of concentrated disinfectant based on quaternary ammonium and glutaraldehyde "Keno Cid 210» solution for 5 minutes effectively inhibits the growth properties of microorganisms. The concentration of the irradiated aqueous disinfectant solution can be 5 times lower than the concentration of the non-irradiated.
\end{abstract}

Key words: ultraviolet radiation, disinfectant, photoactivation, irradiation 
Introduction. As a method of exposure, UV radiation is low-cost and natural, so there is a need to study the effect of ultraviolet radiation on aqueous disinfectant solutions and to determine effective methods of irradiation.

Analysis of recent researches and publications. The effectiveness of photoactivation of water and liquids of various types has been proven by numerous studies [1-3].

Purpose - study of the effect of UV radiation on disinfectants, in particular on their antimicrobial properties, and determine the effective effect of ultraviolet radiation on the tool.

Methods. The high pressure mercury arc lamp DRT-400 lamp was used as a source of ultraviolet radiation. The surface of the aqueous solution was at a distance of $0.25 \mathrm{~m}$ under a source of UV radiation. The photoactivated liquid was applied to the agar medium immediately after inoculation of bacteria. The growth of colonies of microorganisms was recorded 24 hours after application of the treated disinfectant solution.

Bacterial material Staf. aureus was isolated from biological secretions of sick animals. After a bacterial colony of Staf. aureus were grown on meat-peptone agar.

Results. At the Department of Electrical Engineering, Electromechanics and Electrical Technologies of NULES of Ukraine measurements of $\mathrm{pH}$, redox potential of disinfectant solutions immediately after irradiation were carried out. Graphical dependences of the change in the characteristics of the disinfectant are shown in fig. 1, 2.

Studies have shown that irradiation with exposure to ultraviolet radiation for $5 \ldots 15$ min affects the redox potential and $\mathrm{pH}$ of the disinfectant solution. Increasing the duration of irradiation slightly changes the studied parameters. 
$p H$

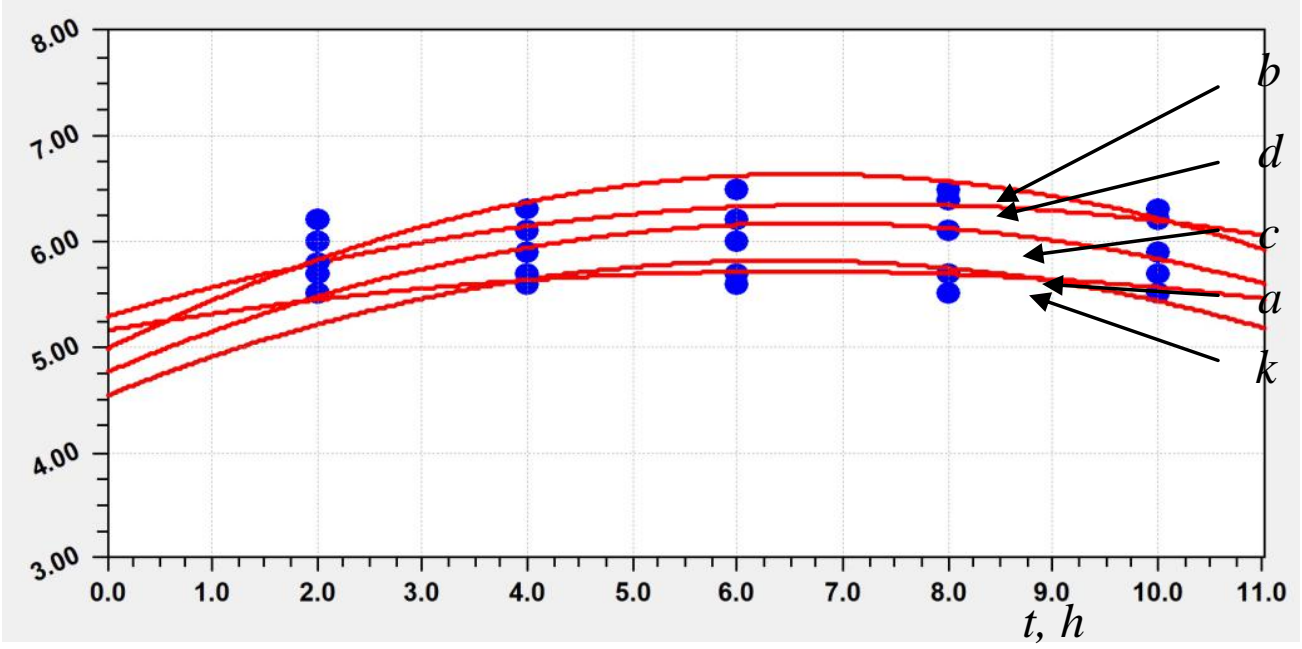

$$
\begin{gathered}
p H_{k}=4,55+0,4 t-0,03 t^{2} ; p H_{2}=5,16+0,17 t-0,01 t^{2} ; \\
p H_{5}=5,29+0,3 t-0,02 t^{2} ; p H_{10}=4,76+4,2 t-0,03 t^{2} ; \\
p H_{15}=4,99+5 t-0,04 t^{2}
\end{gathered}
$$

Fig. 1. Dependence of pH «Keno Cid 210» at different exposure to the storage time of the solution:

$\mathrm{k}$ - control; $\mathrm{a}$ - the duration of irradiation $2 \mathrm{~min} ; \mathrm{b}$ - the duration of irradiation 5 $\min ; \mathrm{c}$ - the duration of irradiation $10 \mathrm{~min}$; $\mathrm{d}$ - the duration of irradiation $15 \mathrm{~min}$

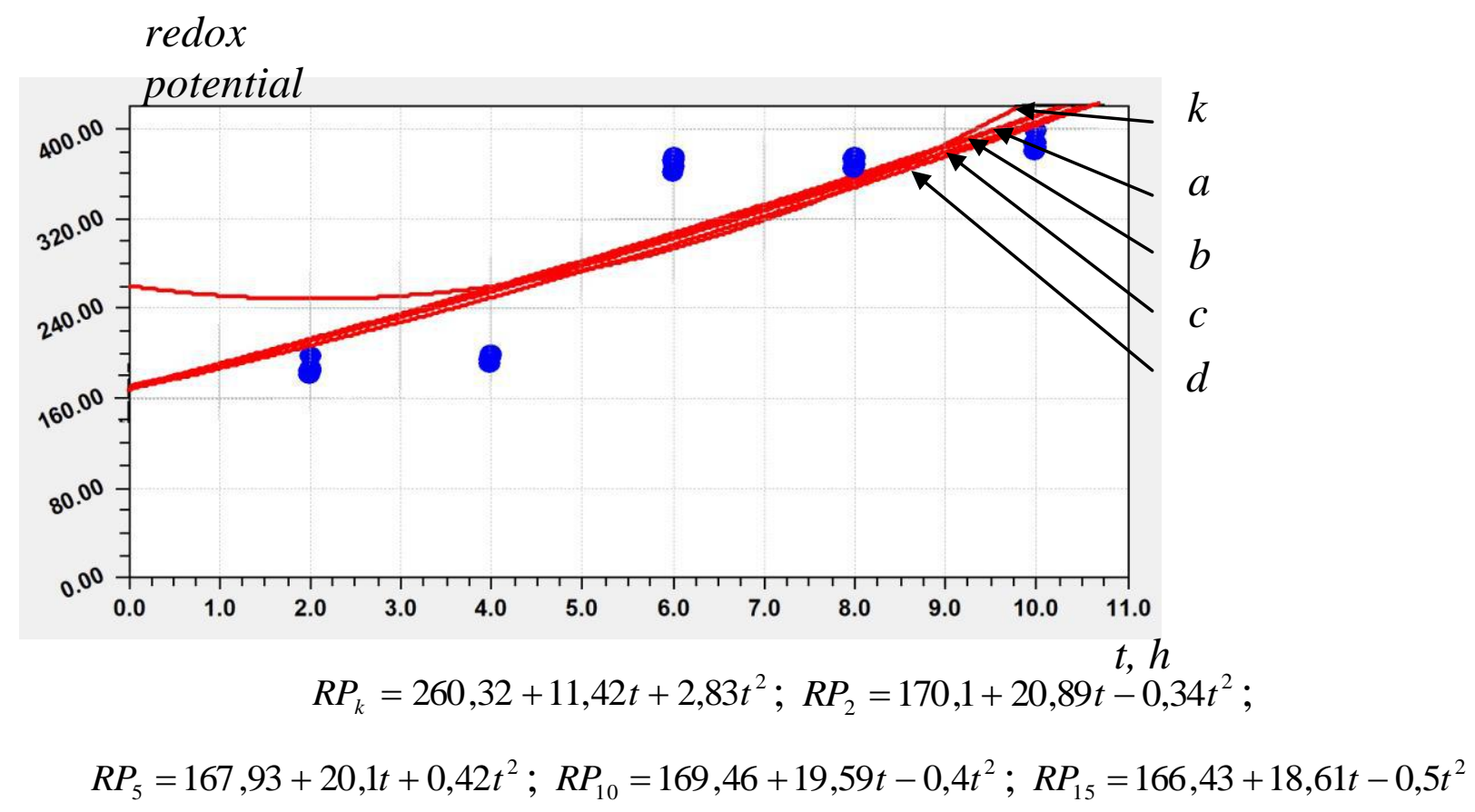

Fig. 2. Dependence of redox potential «Keno Cid 210» at different exposure to the storage time of the solution: 
$\mathrm{k}$ - control; $\mathrm{a}$ - the duration of irradiation $2 \mathrm{~min} ; \mathrm{b}$ - the duration of irradiation 5 $\min ; \mathrm{c}$ - the duration of irradiation $10 \mathrm{~min}$; $\mathrm{d}$ - the duration of irradiation $15 \mathrm{~min}$

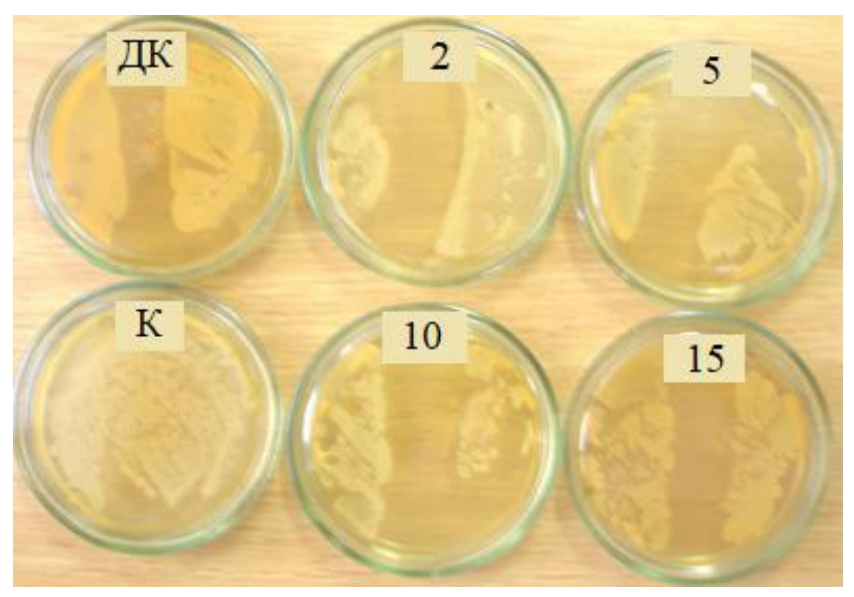

\section{Fig. 3. The effect of disinfectant on the growth properties of staphylococcus:}

$\mathrm{K}$ - control; ДК - the sample was treated with an irradiated solution with a concentration of $0.1 \% ; 2$ - the sample is treated with irradiated solution with an exposure of $2 \mathrm{~min} ; 5$ - with an exposure of $5 \mathrm{~min} ; 10$ - with an exposure of $10 \mathrm{~min} ; 15$ - with an exposure of $15 \mathrm{~min}$

It was found that irradiation with exposure from 5 to 15 min of the solution «Keno Cid 210» effectively enhances its antimicrobial properties. The maximum antimicrobial effect is observed for a solution with an exposure of 5 minutes.

Discussion. It is established that ultraviolet radiation significantly changes the $\mathrm{pH}$ and redox potential of aqueous solutions of disinfectants. The intensity of the parameter change is characteristic of ultraviolet radiation at an exposure of $5 \ldots 15$ minutes.

Irradiation with 5 min exposure to «Keno Cid 210» solution effectively inhibits the growth properties of microorganisms. The concentration of the irradiated aqueous solution of disinfectant can be 5 times lower than the non-irradiated.

\section{References}

1. Chervinskyi, L.S., Bondarenko T.V. (2008) Vplyv fotoaktyvovanoi soniashnykovoi olii na bakterii Klebsiella pneumoniae [Effect of photoactivated 
sunflower oil on Klebsiella pneumoniae]. Pratsi Tavriiskoho derzhavnoho ahrotekhnichnoho universytetu, 8, 106-110.

2. Chervinskyi, L.S., Romanenko, O.I., Knyzhka, T.S. (2017). Teoretychne obhruntuvannia dii enerhii optychnoho vyprominiuvannia na struktury [Theoretical substantiation of the action of the energy of optical radiation on the structure]. Visnyk Kharkivskoho natsionalnoho tekhnichnoho universytetu silskoho hospodarstva imeni Petra Vasylenka, 186, 101-102.

3. Chervinskyi, L. S. Knyzhka, T. S., Romanenko, O. I. (2013) Vplyv elektromahnitnykh poliv na zhyvi orhanizmy i mekhanizmy yikh vplyvu [Influence of electromagnetic fields on living organisms and mechanisms of their influence] Visnyk Kharkivskoho natsionalnoho tekhnichnoho universytetu silskoho hospodarstva imeni Petra Vasylenka, 142, 116-119.

\section{УЛЬТРАФІОЛЕТОВЕ ОПРОМІНЕННЯ ПРЕПАРАТУ «KENO CID 210» \\ Т. С. Книэка, О. І. Романенко, Т.В. Ткачук, Б. М. Блищик}

Анотація. Ефективність процесу фотоактивації водних розчинів доведена проведеними дослідженнями, відображеними в статті.

Як метод впливу, $U V$-випромінювання є низьковартісним та природним, тож виникла потреба вивчити вплив ультрафіолетового випромінювання на водні дезінфікуючі розчини та визначити ефективні способи його опромінення.

Відповідно, існує необхідність дослідити вплив UV-випромінювання на дезінфектанти, зокрема на їх антимікробні властивості та визначити ефективний вплив ультрафіолетового випромінювання на засіб.

Лампа ДРТ-400 використовувалась як джерело ультрафіолетового випромінювання. Поверхня водного розчину знаходилась на відстані 0,25 м під джерелом UV-випромінювання. Фотоактивовану рідину наносили на агарове середовище відразу після посіву бактерій. Була проведена фіксація росту колоній мікроорганізмів зв добу після нанесення обробленого розчину дезінфектанту.

На кафедрі електротехніки, електромеханіки та електротехнологій НУБіП України проведені вимірювання $p H$, окислювально-відновного потенціалу дезінфікуючих розчинів відразу після опромінення. Отримані графічні залежності змін дезінфікуючих властивостей.

Встановлено, що ультрафіолетове випромінювання суттєво змінює рН та окислювально-відновний потенціал водних розчинів дезінфікуючих засобів. Інтенсивність зміни параметрів характерна для ультрафіолетового випромінювання при експозииії 5-15 хвилин.

Опромінення розчину «Кепо Cid 210» протягом 5 хвилин ефективно пригнічуе властивості росту мікроорганізмів. Концентрація опроміненого водного дезінфікуючого розчину може бути в 5 разів нижчою, ніж концентрація неопроміненого.

Ключові слова: ультрафіолетове випромінювання, дезінфікуючий засіб, фотоактивація, опромінення 


\title{
УЛЬТРАФИОЛЕТОВОЕ ОБЛУЧЕНИЕ ПРЕПАРАТА «KENO CID 210»
}

\author{
Т.С. Книжка, А.И. Романенко, Т. В. Ткачук, Б. Н. Блыщик
}

Аннотация. Исследования по облучению жидких сред ультрафиолетовым излучением доказали эффективность этого метода в активачии свойств облучаемых веществ.

Поскольку ультрафиолетовое излучение является естественным и с учетом невысокой стоимости этого метода воздействия на вещества стоит изучить влияние ультрафиолета на водные дезинфицирующие растворы и определить эффективные способы его облучения.

Соответственно, существует необходимость исследовать влияние ультрафиолетового оптического излучения на антимикробные свойства водных дезинфицирующих растворов и определять эффрективное воздействие ультрафиолетового излучения дезинфицирующего средства.

В качестве источника ультрафиолетового излучения использовалась лампа ДРТ-400. Расстояние между источником излучения и поверхностью жидкости составляло 0,25 м. Фотоактивированную жидкость наносили на агаровую среду сразу после посева бактерий. Скорость роста бактерий регистрировали через 24 часа после обработки средь фотоактивированной жидкостью.

С изелью исследования механизма влияния ультрафиолетового излучения на физические свойства дезинфищирующих растворов на кафедре электротехники, электромеханики и электротехнологий НУБиП Украины измеряли $p H$, окислительно-восстановительный потенциал дезинфицирующих растворов сразу после облучения. Получены графические зависимости изменения дезинфицирующих свойств.

Было обнаружено, что ультрафиолетовое излучение значительно изменяет pH $и$ окислительно-восстановительный потенциал водных растворов дезинфицирующих средств. Интенсивность изменения водородных параметров характерна для ультрафиолетового излучения с выдержкой 5-15 минут.

Облучение с выдержкой в течение 5 минут раствора «Kепо Cid 210» эффективно подавляет ростовые свойства микроорганизмов. Концентрация облученного водного дезинфицирующего раствора может быть в 5 раз ниже, чем у необлученного.

Ключевые слова: ультрафиолетовое излучение, дезинфицирующее средство, фотоактивация, облучение 